\title{
Short communication: Molecular epidemiology of Streptococcus agalactiae differs between countries
}

\author{
J. Reyes, ${ }^{*} \dagger^{1}$ M. Chaffer, ${ }^{*}$ Juan Carlos Rodriguez-Lecompte, $\ddagger$ Javier Sánchez, ${ }^{*}$ Ruth N. Zadoks, $\#$ \\ Natasha Robinson,II Ximena Cardona, I N. Ramírez, ${ }^{* *}$ and G. P. Keefe* \\ *Department of Health Management, Atlantic Veterinary College, University of Prince Edward Island, Charlottetown, Prince Edward Island, \\ Canada C1A 4P3 \\ †Biogenesis Research Group, Faculty of Agricultural Sciences, University of Antioquia, Calle 70 No. 52-21, C.P. 050010 Medellin, Colombia \\ ‡Department of Pathology and Microbiology, Atlantic Veterinary College, University of Prince Edward Island, Charlottetown, Prince Edward Island, \\ Canada C1A 4P3 \\ §Moredun Research Institute, Penicuik, Scotland, UK, EH26 OPZ \\ \#Institute of Biodiversity, Animal Health and Comparative Medicine, College of Medical, Veterinary and Life Sciences, University of Glasgow, \\ UK, G61 1QH \\ IIMaritime Quality Milk Laboratory, Atlantic Veterinary College, University of Prince Edward Island, Charlottetown, Prince Edward Island, \\ Canada C1A 4P3 \\ đCooperativa COLANTA, CRA 64C, 72-160 Medellín, Colombia \\ **Epidemiology and Public Health, Centauro Research Group, Faculty of Agricultural Sciences, University of Antioquia, Calle 70 No. $52-21$ \\ C.P. 050010 Medellín, Colombia
}

\section{ABSTRACT}

Group B Streptococcus or Streptococcus agalactiae continue to be challenging for milk quality programs in countries with emerging dairy industries, such as Colombia, where high prevalence has been reported. Molecular typing of isolates is needed to understand the variability and epidemiology of this pathogen and to develop effective control and eradication programs. We characterized the molecular profile of Strep. agalactiae isolated from cows with subclinical mastitis in 21 Colombian dairy herds and measured diversity within and between herds using multilocus sequence typing. Isolates belonged to sequence type 248 [clonal complex (CC) $103 ; \mathrm{n}=30)$, ST1 (CC1; $\mathrm{n}=6)$ or ST22 (CC22; $\mathrm{n}=4)$ ], whereas members of CC67/61, the dominant type in North America, were not detected. Presence of multiple clonally unrelated sequence type within a herd was common, which contrasts with the situation in European countries and suggests introduction from multiple sources. Our results demonstrate that conclusions from molecular epidemiological studies in 1 region cannot necessarily be extrapolated to other regions, and no single bovine-adapted CC of Strep. agalactiae exists in Colombia. Improvements in internal and external biosecurity will be needed to reduce Strep. agalactiae prevalence in Colombian dairy herds.

Key words: subclinical mastitis, Streptococcus agalactiae, molecular epidemiology

Received June 20, 2017.

Accepted July 30, 2017.

${ }^{1}$ Corresponding author: jreyes@upei.ca

\section{Short Communication}

Streptococcus agalactiae or Group B Streptococcus is a common cause of bovine subclinical mastitis in countries with emerging dairy industries and is a reemerging pathogen in European countries with longstanding mastitis control programs (Katholm et al., 2012; Keefe, 2012). Group B Streptococcus is also an important pathogen in people. It is the major cause of infectious disease in neonates in western countries and it is recognized as emerging pathogen in adults worldwide. People can also be asymptomatic carriers of the organism (Brochet et al., 2006; Lyhs et al., 2016). Streptococcus agalactiae is a very common pathogen of dairy cattle in several regions of Colombia, with prevalence estimates of 11 to $60 \%$ at the herd level (Keefe et al., 2011) and 35\% at the cow level (Ramírez et al., 2014).

Molecular methods have been used to gain insight into the pathophysiology and epidemiology of Strep. agalactiae in dairy herds, whereby different methods serve different purposes (Zadoks et al., 2011). Comparative methods, such as pulsed-field gel-electrophoresis and random amplified polymorphic DNA (RAPD) typing, have been used for within-herd studies over short spatiotemporal scales because of their relatively high discriminatory power, whereas multilocus sequence typing (MLST) is more suited for studies at a large spatiotemporal scale, such as comparison of populations across herds or countries, because it is a universal typing system based on slowly evolving housekeeping genes (Mahmmod et al., 2015; Jørgensen et al., 2016; Lyhs et al., 2016). Whole-genome sequencing has primarily been used to study host adaptation of Strep. agalactiae 
(Richards et al., 2011; Richards et al., 2013; Almeida et al., 2016), and may replace other methods as a tool for population-level studies now that next-generation sequencing is making it increasingly rapid and affordable. When MLST was first applied to bovine isolates, it was suggested that a single bovine-adapted clonal complex (CC), CC67, was responsible for the majority of bovine mastitis (Bisharat et al., 2004). All isolates in that study originated from the United Kingdom, and CC67 is still the most common type of Strep. agalactiae in Scotland (R. Zadoks, unpublished data). Different types of Strep. agalactiae dominate in cattle in studies from other countries (e.g., CC1 in northern Europe or CC103 in China; Zadoks et al., 2011; Yang et al., 2013; Lyhs et al., 2016). Little is known about the dominant CC of Strep. agalactiae in South America in general, or about its molecular epidemiology in Colombia in particular. The aim of the current study was to investigate the sequence type $(\mathbf{S T})$ and CC present in a collection of Strep. agalactiae isolates from Colombian dairy herds to identify important strains, potential sources, and routes of transmission.

Isolates for this research were part of Ramírez et al. (2014) study (January 2009 to August 2011) in the northern region of Antioquia, Colombia. Pre- and postmilking teat disinfection were used in most study herds (90.4\%), and hand milking was twice as common as machine milking. Within-herd heterogeneity was initially assessed using RAPD typing was conducted on isolates from 100 milk samples obtained from 66 cows with subclinical mastitis originating from 23 herds, whereby subclinical mastitis was defined as a cow-level SCC above 200,000 cells $/ \mathrm{mL}$ in the absence of visible abnormalities of the milk or udder (Reyes Velez, 2016). For DNA extraction, individual colonies of Strep. agalactiae were collected from culture plates and suspended in 1.5 $\mathrm{mL}$ of tripticase soy broth with overnight incubation at $37^{\circ} \mathrm{C}$. Genomic DNA was extracted with the DNeasy Blood \& Tissue Kit following the manufacturer's procedure (Qiagen, Hilden, Germany), resuspended in 100 $\mathrm{mL}$ of TE buffer (10 $\mathrm{m} M$ Tris, $1 \mathrm{~m} M$ EDTA) and stored in Eppendorf tubes. The DNA was sent to the Atlantic Veterinary College. Quantity and quality of DNA were assessed using $1 \mu \mathrm{L}$ of the sample and measured with a NanoDrop 1000 spectrophotometer (Thermo Scientific Inc., Wilmington, DE); RAPD typing was performed to determine within-herd heterogeneity (data not shown; Reyes Velez, 2016). Based on RAPD typing, 1 or 2 types per herd were identified. (Reyes Velez, 2016). Using 1 isolate per RAPD type per herd, 40 isolates from 35 cows in 21 herds were selected for MLST. Two isolates from 2 different herds were not considered for further MLST analysis due to low DNA quality. The MLST was implemented using the high-throughput
HiMLST method at Streeklab Haarlem (Haarlem, the Netherlands; Boers et al., 2012). Allelic profiles and ST were assigned to each isolate through comparison with the PubMLST database for Strep. agalactiae (http:// pubmlst.org/sagalactiae) and grouped using eBURST (based upon related sequence types) version 3 software (http://eburst.mlst.net/; Feil et al., 2004). To avoid amalgamation of previously separate $\mathrm{CC}$ into a single $\mathrm{CC}, \mathrm{CC}$ were named using modified nomenclature as also implemented in other studies (Lopez-Sanchez et al., 2012; Springman et al., 2014).

Three ST were identified, ST248, ST1, and ST22, found in 75,15 , and $10 \%$ of isolates, respectively, and in 81,33 , and $19 \%$ of herds; the $3 \mathrm{ST}$ belong to distinct CC (i.e., ST248 to subCC103, ST1 to subCC1, and ST22 to subCC22). Figure 1 shows the population snapshot for the isolates obtained in this study and the existing Strep. agalactiae pubMLST database. Multiple clonally unrelated ST were identified in as many as 1 in 3 herds, and sometimes even within individual cows. Two cows were infected by 2 ST (i.e., ST248 in combination with ST1 or ST22), whereby the different ST were obtained on the same day but from different quarters. A total of 25,5 , and 3 cows were infected with a single ST (i.e., ST248, ST1, and ST22, respectively).

Presence of multiple ST of Strep. agalactiae within a dairy herd has also been reported in China, albeit at lower frequency (4 of 21 herds; Yang et al., 2013). By contrast, in northern Europe, only 1 ST was detected in most herds (Mahmmod et al., 2015; Jørgensen et al., 2016; Lyhs et al., 2016). If a second ST was detected in a herd in northern Europe, this would generally be a single locus variant of the dominant strain in that herd rather than a clonally unrelated ST (Mahmmod et al., 2015). Presence of multiple unrelated ST per herd, as observed in our study in Colombia, suggests introduction of Strep. agalactiae into the herd from multiple sources (e.g., via purchase of cattle). This phenomenon has previously been described for Staphylococcus aureus, where the number of strains per herd is associated with cattle importation practices (Middleton et al., 2002). In Denmark, introduction of Strep. agalactiae into herds was not linked to cattle movements, implying that a nonbovine source of the organism must exist (Mweu et al., 2014). In northern Europe, people were identified as a potential source of Strep. agalactiae for dairy cattle (Zadoks et al., 2011; Lyhs et al., 2016).

In addition to differences in within-herd heterogeneity, differences have been noted between countries in predominant ST. In a study from China, as in the current study from Colombia, subCC103 predominated (Yang et al., 2013). By contrast, subCC1, which was a minor CC in Colombia, dominated in Denmark, Finland, and Sweden (Zadoks et al., 2011; Lyhs et al., 
2016). In the United Kingdom, subCC67 predominated, and it has been proposed that this should be considered a bovine-adapted CC. Results from Colombia, China, and northern Europe clearly demonstrate that subCC67 is not the only bovine-adapted clade. The third ST that was detected in Colombia, ST22, is related to both subCC17 and subCC67 but is not considered part of either (Lopez-Sanchez et al., 2012). The ST103 has recently been identified in dairy herds with environmental Strep. agalactiae (Jørgensen et al., 2016). Considering the predominance of a member of CC103 in Colombian dairy herds, it would be of interest to explore the possible existence of environmental sources in such herds. In humans, members of CC103 are rarely detected, although ST248 was originally identified in human urine. (Brochet et al., 2006). In humans, ST1 is commonly found and is predominantly associated with healthy carriers rather than disease (Lyhs et al., 2016). Based on prevalence and clinical manifestations in other countries, CC1 seems the most likely candidate for interspecies transmission among the 3 dominant types in Antioquia, but no data are available on the distribution of human Strep. agalactiae $\mathrm{ST}$ in this region.

In conclusion, molecular characterization of the Strep. agalactiae population in dairy herds in Antioquia, Colombia, indicated that there are $3 \mathrm{ST}$ in this region; that the relative proportion of these types differs from the distribution in other geographic regions; and that co-existence of 2 types within herds is more common than elsewhere. The distribution of these ST could also suggest that within- and between-herd transmissions occur due to lack of internal and external biosecurity. The observed difference in within-herd heterogeneity between non-European countries (Colombia and China) and European countries (UK, Denmark, and Finland) demonstrates that it is important to consider national or regional differences when designing mastitis control programs. The difference in distribution of dominant ST between countries and continents further empha-

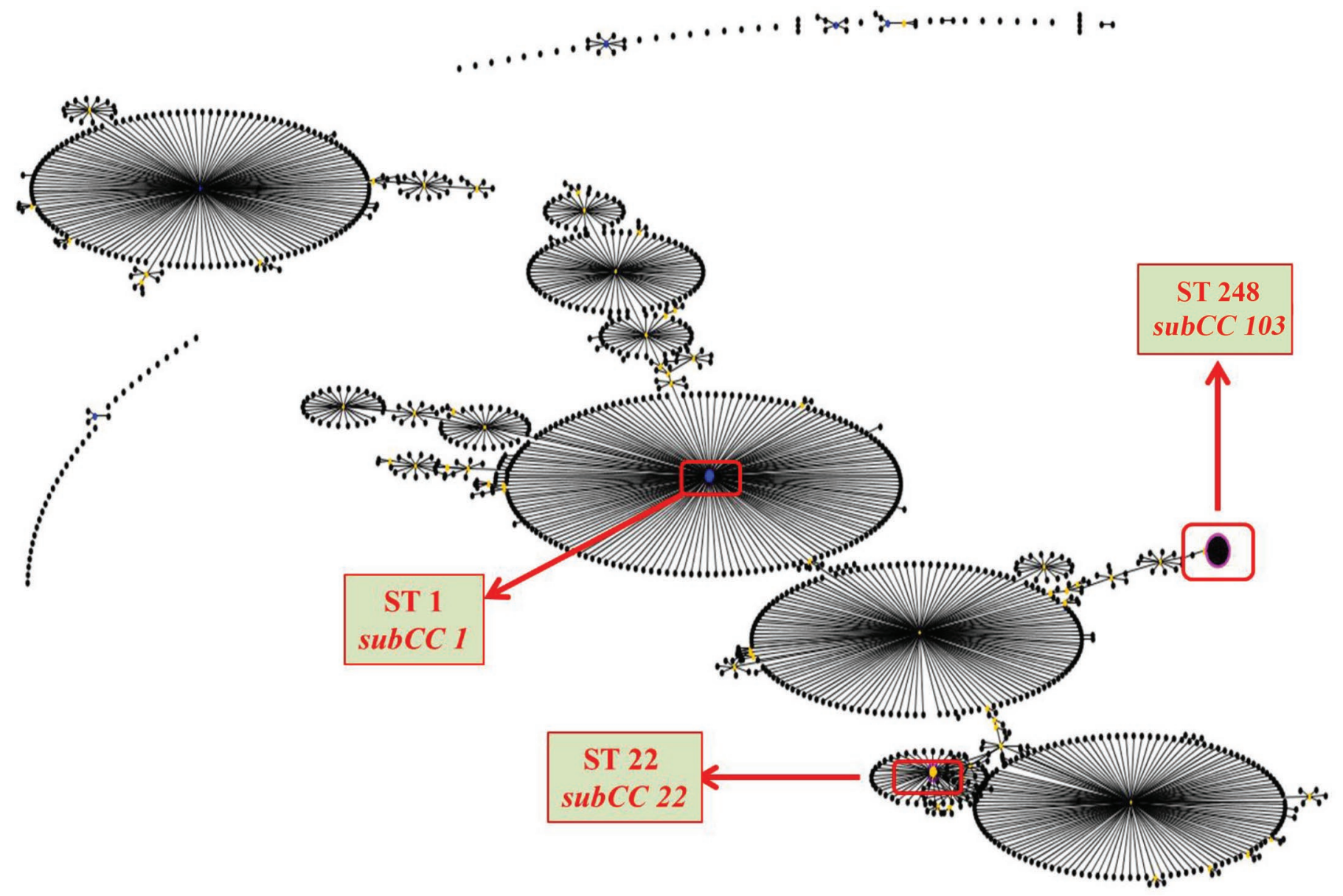

Figure 1. Population snapshot of Streptococcus agalactiae, showing the frequency of sequence types (ST) identified among 40 nonrandomly selected isolates from dairy cattle in Colombia. eBURST groups including ST from Colombia are marked with the squares. CC $=$ clonal complex. Color version available online. 
sizes that results from Strep. agalactiae studies in one country do not necessarily represent the situation in a different country.

\section{ACKNOWLEDGMENTS}

The authors thank William Chalmers (Editorial Service, Canada Excellence Research Chair in Aquatic Epidemiology, University of Prince Edward Island, Charlottetown, PE, Canada) and Marguerite Cameron (postdoctoral research fellow, Department of Health Management, Atlantic Veterinary College, University of Prince Edward Island, Charlottetown, PE, Canada) for assistance in the preparation of the manuscript and Diana Macias (COLANTA) for laboratory technical assistance. The authors acknowledge the Interamerican Institute for Cooperation on Agriculture (IICA, Ottawa, ON, Canada; Internship program A5C-RIAP 2012-07, 2012), and Ministerio de Agricultura y Desarrollo Rural de Colombia (Bogotá, Colombia), which provided funding. Furthermore, to the Cooperativa COLANTA Ltda, Federación de Asociaciones de Ganaderos (FAGA, Medellín, Colombia), and the Sustainability Project 20132014 (Estrategia de sostenibilidad CODI 2013-2014, University of Antioquia), which provided administrative support for the project. Personal funding for Julian Reyes was provided by Innovation PEI (Charlottetown, PE, Canada) and Colciencias (Bogotá, Colombia).

\section{REFERENCES}

Almeida, A., C. Alves-Barroco, E. Sauvage, R. Bexiga, P. Albuquerque, F. Tavares, I. Santos-Sanches, and P. Glaser. 2016. Persistence of a dominant bovine lineage of group B Streptococcus reveals genomic signatures of host adaptation. Environ. Microbiol. 18:4216-4229. https://doi.org/10.1111/1462-2920.13550.

Bisharat, N., D. W. Crook, J. Leigh, R. M. Harding, P. N. Ward, T. J. Coffey, M. C. Maiden, T. Peto, and N. Jones. 2004. Hyperinvasive neonatal group B Streptococcus has arisen from a bovine ancestor. J. Clin. Microbiol. 42:2161-2167. https://doi.org/10.1128/JCM.42 $.5 .2161-2167.2004$.

Boers, S. A., W. A. van der Reijden, and R. Jansen. 2012. Highthroughput multilocus sequence typing: Bringing molecular typing to the next level. PLoS One 7:e39630. https://doi.org/10.1371/ journal.pone.0039630.

Brochet, M., E. Couvé, M. Zouine, T. Vallaeys, C. Rusniok, M.-C. Lamy, C. Buchrieser, P. Trieu-Cuot, F. Kunst, C. Poyart, and P. Glaser. 2006. Genomic diversity and evolution within the species Streptococcus agalactiae. Microbes Infect. 8:1227-1243. https://doi .org/10.1016/j.micinf.2005.11.010.

Feil, E. J., B. C. Li, D. M. Aanensen, W. P. Hanage, and B. G. Spratt. 2004. eBURST: Inferring patterns of evolutionary descent among clusters of related bacterial genotypes from multilocus sequence typing data. J. Bacteriol. 186:1518-1530. https://doi.org/10.1128/ JB.186.5.1518-1530.2004.

Jørgensen, H. J., A. B. Nordstoga, S. Sviland, R. N. Zadoks, L. Sølverød, B. Kvitle, and T. Mørk. 2016. Streptococcus agalactiae in the environment of bovine dairy herds - Rewriting the textbooks? Vet. Microbiol. 184:64-72. https://doi.org/10.1016/j.vetmic.2015 .12 .014 .
Katholm, J., T. W. Bennedsgaard, M. T. Koskinen, and E. Rattenborg. 2012. Quality of bulk tank milk samples from Danish dairy herds based on real-time polymerase chain reaction identification of mastitis pathogens. J. Dairy Sci. 95:5702-5708. https://doi.org/ 10.3168/jds.2011-5307.

Keefe, G. 2012. Update on control of Staphylococcus aureus and Streptococcus agalactiae for management of mastitis. Vet. Clin. North Am. Food Anim. Pract. 28:203-216. https://doi.org/10.1016/j .cvfa.2012.03.010.

Keefe, G., M. Chaffer, A. Ceballos, M. Londoño, M. Jaramillo, and M. Toro. 2011. Effects of Streptococcus agalactiae on the Colombian dairy industry. Pages 156-159 in 3rd International Symposium on Mastitis and Milk Quality. National Mastitis Council, St. Louis, MO.

Lopez-Sanchez, M.-J., E. Sauvage, V. Da Cunha, D. Clermont, E. Ratsima Hariniaina, B. Gonzalez-Zorn, C. Poyart, I. RosinskiChupin, and P. Glaser. 2012. The highly dynamic CRISPR1 system of Streptococcus agalactiae controls the diversity of its mobilome. Mol. Microbiol. 85:1057-1071. https://doi.org/10.1111/j .1365-2958.2012.08172.x.

Lyhs, U., L. Kulkas, J. Katholm, K. P. Waller, K. Saha, R. J. Tomusk, and R. N. Zadoks. 2016. Streptococcus agalactiae serotype IV in humans and cattle, northern Europe. Emerg. Infect. Dis. 22:20972103. https://doi.org/10.3201/eid2212.151447.

Mahmmod, Y. S., I. C. Klaas, J. Katholm, M. Lutton, and R. N. Zadoks. 2015. Molecular epidemiology and strain-specific characteristics of Streptococcus agalactiae at the herd and cow level. J. Dairy Sci. 98:6913-6924. https://doi.org/10.3168/jds.2015-9397.

Middleton, J. R., L. K. Fox, J. M. Gay, J. W. Tyler, and T. E. Besser. 2002. Use of pulsed-field gel electrophoresis for detecting differences in Staphylococcus aureus strain populations between dairy herds with different cattle importation practices. Epidemiol. Infect. 129:387-395.

Mweu, M. M., S. S. Nielsen, T. Halasa, and N. Toft. 2014. Spatiotemporal patterns, annual baseline and movement-related incidence of Streptococcus agalactiae infection in Danish dairy herds: 2000-2009. Prev. Vet. Med. 113:219-230. https://doi.org/10.1016/ j.prevetmed.2013.10.020.

Ramírez, N. F., G. Keefe, I. Dohoo, J. Sánchez, O. Arroyave, J. Cerón, M. Jaramillo, and L. G. Palacio. 2014. Herd- and cow-level risk factors associated with subclinical mastitis in dairy farms from the High Plains of the northern Antioquia, Colombia. J. Dairy Sci. 97:4141-4150. https://doi.org/10.3168/jds.2013-6815.

Reyes Velez, J. 2016. Streptococcus agalactiae subclinical mastitis epidemiology and control in Colombian dairy herds. Doctoral thesis. Department of Health Management, Atlantic Veterinary College, University of Prince Edward Island, Charlottetown, PE, Canada.

Richards, V. P., S. C. Choi, P. D. P. Bitar, A. A. Gurjar, and M. J. Stanhope. 2013. Transcriptomic and genomic evidence for Streptococcus agalactiae adaptation to the bovine environment. BMC Genomics 14:920. https://doi.org/10.1186/1471-2164-14-920.

Richards, V. P., P. Lang, P. D. Pavinski Bitar, T. Lefébure, Y. H. Schukken, R. N. Zadoks, and M. J. Stanhope. 2011. Comparative genomics and the role of lateral gene transfer in the evolution of bovine adapted Streptococcus agalactiae. Infect. Genet. Evol. 11:1263-1275. https://doi.org/10.1016/j.meegid.2011.04.019.

Springman, A. C., D. W. Lacher, E. A. Waymire, S. L. Wengert, P. Singh, R. N. Zadoks, H. D. Davies, and S. D. Manning. 2014. Pilus distribution among lineages of group B Streptococcus: An evolutionary and clinical perspective. BMC Microbiol. 14:159.

Yang, Y., Y. Liu, Y. Ding, L. Yi, Z. Ma, H. Fan, and C. Lu. 2013. Molecular characterization of Streptococcus agalactiae isolated from bovine mastitis in eastern China. PLoS One 8:e67755. https://doi .org/10.1371/journal.pone.0067755.

Zadoks, R. N., J. R. Middleton, S. McDougall, J. Katholm, and Y. H. Schukken. 2011. Molecular epidemiology of mastitis pathogens of dairy cattle and comparative relevance to humans. J. Mammary Gland Biol. Neoplasia 16:357-372. https://doi.org/10.1007/s10911 $-011-9236-y$. 